\title{
Good Fences Make Good Neighbors?
}

\author{
Steven N. Handel
}

W e all have boundaries to negotiate in life. There are personal boundaries, when to participate in or communicate with another person's life. There are ethical boundaries, as we determine what is moral in each of our actions. There are physical boundaries that confine our movements and experiences, narrowing our life path. Professionally, our restoration ecology projects confront us with even more boundaries, conceptual and tangible ones, which affect the success and trajectory of our work.

The landscapes we work to restore have both regulatory and hardscape boundaries. The regulatory boundaries in our communities are often labeled as residential, industrial, commercial, or open space zones. The divisions among the zones are precisely drawn and registered on plan maps which have much legal power. These boundaries often do not correspond to ecological reality. The boundary between any two adjacent zones is a lively ecological place with organisms and environmental processes that are hindered or blocked by the nature of that civic-defined edge.

Unfortunately, the ecological zones needed for survival can be wide, and are rarely congruent with our land-use map boundaries. Those civic boundaries can drive the restorationist up against the wall, however that wall is zoned. We look over the boundary wall and see ecological needs and links which are often invisible to those focused on human-centric goals. Animals and plant diapores move widely across the landscape, search for food, nesting areas, or germination sites. Those adjacent areas to restoration projects are critical for our project's long-term success. They offer resources which are necessary for the parcels we wish to advance ecologically.

So we struggle with fences. Sometimes we put up fences against intruders, an abundance of deer, of kids on mountain bikes, or of seeds of invasive species being blown into our project's soil. Sometimes the fences separate our work from useful organisms. We need the natural introduction of seed and animal species that we cannot buy from our local suppliers. Most restoration projects have a sizable budget for plant material, but who purchases mutualistic insects or perching birds needed for ecological function? There are commercial sources for a few beetles and pollinating bee

Ecological Restoration Vol. 32, No. 1, 2014

ISSN 1522-4740 E-ISSN 1543-4079

C2014 by the Board of Regents of the University of Wisconsin System. species, but these are drops in the beneficial insect bucket we will need to fill for sustainable project design.

At a longer time perspective, changing climates will result in population ranges migrating to new areas as birth and death rates are altered. Hardscape features such as roads, high-rise buildings or wide mowed lawns are surrogate fences, although called by other names. That which we call a road by any other name would smell as troublesome. The constructions block habitat migration necessary for an ecological future. Oh, they are called expressways, but major roads are ribbons of molasses slowing species movement in a rapidly changing climatic world. The toll roads take their toll on dispersal processes.

We take the position that these varied land-use zones are, in fact, one ecological zone that has been fractured by civic decisions and structures that have ignored ecological function. We must find a way to layer ecological function over commercial and planning decisions that have made regulatory fences. Sometimes, regulatory fences are made across single habitat types, as when state and municipal boundaries are drawn, and different staff, budgets, and decisions deal differently with similar ecological issues on opposite sides of the mapped boundary. A restorationist may, for example, have to manage a habitat without power to stop a threatening population of some invasive species just meters away, but on land which is beyond her ability to manage.

The poet Robert Frost wrote,

"Before I built a wall I'd ask to know

What I was walling in or walling out,"

In our world that "what" can be ecological function and landscape dynamics. The principles of landscape ecology, now well taught in biologically-based programs, are rarely incorporated into planning or architectural decisions. The drawing of zoning boundaries and rules, profound legal steps, are usually not determined by ecological need. Our natural communities need biotic communication with surrounding areas, the living neighbors that can contribute to successional health. Good fences, legal, structural, or conceptual, so often deny the many ecological needs for good neighbors.

"Something there is that does not love a wall." 
How can we mend this breach between restoration ecology reality and civic practice?

\section{Recommended References}

Bennett, A.F. 2003. Linkages in the Landscape: The Role of

Corridors and Connectivity in Wildlife Conservation. Gland, Switzerland: IUCN.
Forman, R.T.T. 1995. Land Mosaics: The Ecology of Landscapes and Regions. New York, NY: Cambridge University Press.

Forman, R.T.T. 2003. Road Ecology: Science and Solutions. Washington, D.C.: Island Press.

Frost, R. 1968. Complete Poems. New York, NY: Holt, Rinehart, and Winston.

Lundquist, J., E. Andersson, G. Cleary and T. Elmqvist. 2008. Linkages beyond borders; targeting spatial processes in fragmented urban landscapes. Landscape Ecology 23:717-726.

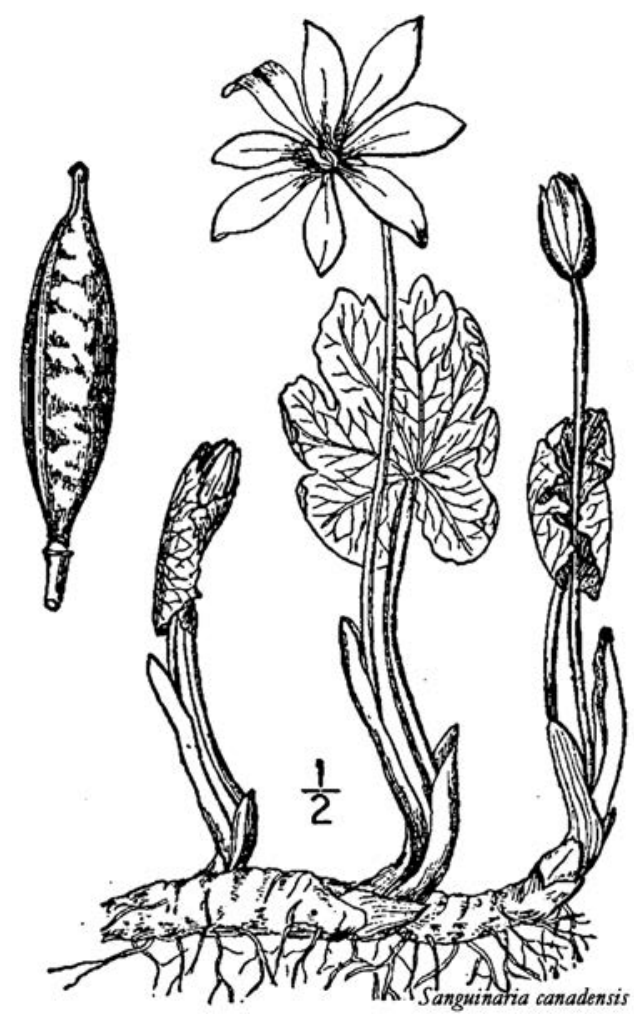

USDA-NRCS PLANTS Database / Britton, N.L. and A. Brown. 1913. An Illustrated Flora of the Northern United States, Canada and the British Possessions, Vol. 2. New York, NY: Charles Scribner's Sons. 